\title{
Implementing Promotional Mix at an SME with the Help of Business Coaching
}

\author{
Muhammad Hilmy Hawari ${ }^{1}$, Lily Sudhartio ${ }^{2}$ \\ \{hilmy.hawari@gmail.com ${ }^{1}$, lily.sudhartio@gmail.com² \\ Universitas Indonesia, Salemba, Jakarta, Indonesia ${ }^{1}$, Universitas Indonesia, Salemba, Jakarta, Indonesia ${ }^{2}$
}

\begin{abstract}
This paper describes the process of business coaching in a Small and Medium Enterprise (SME). The purpose of this study is to help an SME to resolve their problems. This study consists of several steps including problem identification, strategy formulation, strategy implementation, and then strategy observation and evaluation. The outcome of this study is to implement the most appropriate strategy. This research tries to design promotional mix to resolve problems faced by an SME. To give a thorough perspective on the usage of this approach, a case study using Soul Sepatu, an SME engaged in the shoe laundry industry in Rawamangun, Jakarta, Indonesia, is conducted.
\end{abstract}

Keywords: Business Coaching; Digital Marketing; Promotional Mix; Sales Promotion; Shoe Laundry; SME

\section{Introduction}

According to the Indonesian Ministry of Industry in 2019, footwear industry is one of the growing industries in Indonesia. Footwear has a lot of contributions to the Indonesian national economy. Indonesia is the fourth biggest manufacturer of footwear in the world, with a total contribution of $4,6 \%$ to the world footwear production in 2018. Indonesian Ministry of Industry also noted that there is a significant increase in footwear consumption from two pairs a year to more than three pairs a year in the period of 2012 to 2016 [1].

Today, shoe is no longer just a footwear, but shoe can show a person's identity and social class. As a symbol of identity and social class, more people are giving more attention to their shoes. Indonesia, as a tropical country, has a high rainfall so shoes can easily get dirty. With that condition, a need for people to be able to keep their shoe clean and shiny at all time emerge. This condition present opportunities for a company to help people maintain and clean their precious shoe/s and become the reason for the establishment of shoe laundry industry. To harness this opportunity, a lot of Small and Medium Enterprise (SME) was established including Soul Sepatu.

As a business entity, Soul Sepatu has a vision to always grow every year. Yet, for the last second half of 2019, Soul Sepatu Rawamangun was unable to achieve the targeted sales number even once. In order to grow organically, Soul Sepatu must grow from the inside, and one of the growth indicators are sales. Soul Sepatu Rawamangun's failure to meet the targeted sales number is due to customer's lack of knowledge or information about Soul Sepatu itself and shoe laundry in general. With this condition, one of the tools that can be used to increase sales is promotional mix.

This paper endeavors to identify and resolve the problem faced by Soul Sepatu as an SME in Indonesia. A case study is conducted to determine the cause, formulate the proper strategy, implement the strategy, and evaluate the changes. The outline of this paper proceeds as 
follows, an introduction is given in section 1, in section 2, related literature is explored to gain insight into the current problem. The research methodology in which this study is conducted is then presented in section 3. In section 4, the result of the study is presented. A discussion of the result will be done in section 5 and the paper will be concluded in the final section.

\section{Literature review}

Promotion is defined as a thorough coordination by seller to develop information and persuasion channel to sell goods and services or to promote an idea. Most of the organization's marketing communication program is a well-controlled and well-planned promotion program [2]. Integrated Marketing Communication (IMC) is the guiding principle for the organization or company to follow in order to communicate effectively with their target market [3]. IMC is a tool to help organizations coordinate all promotional activities to achieve a unified and customer-focused promotional message [4]. Those promotional activities are called promotional mix.

The traditional promotional mix consists of four elements which are advertising, personal selling, sales promotion, and public relations. However, recent study has added two more elements, direct marketing and digital/internet marketing [2]. In designing promotional mix, we need to understand the firms structural designs so we can better leverage the effect of promotional mix [5]. In the current research, we will be focusing on sales promotion and digital/internet marketing.

Sales promotion is commonly defined as marketing activities that give additional value or incentive to sales force, distributor, or customer in order to stimulate sales directly [2]. Sales promotion often used to instantly stimulate consumers to buy more goods or services provided [6]. Sales promotion can be broadly categorized into monetary and non-monetary sales promotion. The way the organization do sales promotion can impact customer perceived value in regard to the benefit given to the customer [7]. Sales promotion can also boost sales, however, the impact is depending on the type of product class and the form of sales promotion the organization chooses [8].

The next promotional mix is digital/internet marketing. The internet is a marketing communication tool that has a wide array of functions. The internet is an advertising media which often used for promoting products or services. Apart from advertising, the internet can also be used to do direct marketing, personal selling, and publicity/public relations activities more efficiently. We live in an era called Marketing 4.0, where we have to integrate digital marketing with traditional marketing in order to win customer advocacy [9]. One such digital media is called social media [2]. The advent of social media has become a major factor that influences consumer behavior [3]. That is why social media or digital/internet media in general must be integrated in designing the promotional mix.

\section{Method}

\subsection{Research setting}

The setting of this research is in a company called Soul Sepatu. Soul Sepatu is a company that can be categorized as a small enterprise according to Indonesian SME Law No. 20 of 
2008. Soul Sepatu is a company specializing in shoe laundry business. Not only cleaning shoes, they can also help the customer if they want to clean their bags or hats, and Soul Sepatu also receives order to fix their shoes, bags, or hats. Soul Sepatu has three branches, two in Bekasi and one in Jakarta.

Considering that Soul Sepatu is specialized in shoe laundry and has several branches, this research will be focused on Soul Sepatu's Rawamangun branch, Jakarta, Indonesia in order to sharpen the analysis. The location chosen is based on the branch that has the least sales report in the second half of 2019. The sales reports are 200 pairs average at the Rawamangun branch, it is way smaller compared to other branches with sales up to 400 pairs average. The company has a target of at least 300 pairs of shoes processed each month, assuming it has two workers on the Rawamangun branch. This lower than the target numbers indicate that some problem is happening that makes the Rawamangun branch unable to achieve the desired sales number.

\subsection{Research method}

The low sales number becomes the starting point of this research. This research endeavors to determine the cause of the low sales number. Using relevant theory that has been described in the previous segment and using the data gathered, this research will try to present and implement a solution to Soul Sepatu Rawamangun. In order to effectively implement a strategy, the researcher and the business owner will collaborate to create the most suitable plan of action. For a successful strategy to be implemented, cooperation is essential and periodic evaluations are also needed.

This research is conducted using business coaching. Business coaching is a collaborative relationship between a coach and a business owner in order to contribute positively to firm performances and goals [10]. The researcher is acting as a coach and the business owner is acting as a recipient while also collaborating to develop a solution. This research combines business coaching with qualitative techniques in order to generate and analyze data, draw conclusions, and propose solutions to the problem. This business coaching was conducted for nine months from October 2019 to June 2020.

The researcher gathers data through online articles, the company's internal data (such as sales report), direct observation, interviews with owner and other stakeholders, and questionnaires. Online articles and questionnaires will be helpful in analyzing the external environment such as industry and market condition. A semi-structured interview and a simple questionnaire are used as a method to understand the internal condition of the company. The interview with key respondents were also used to explore the actual condition of the company and to develop the solution. The questionnaire is given to customers and the local community to grasp the actual performance of the company through their perception. The knowledge acquired from the data analysis will become actionable when it is interpreted, put in the right context, and acted upon [11]. In this case, the coach and the business owner (1) plan together the best strategy based on the data, (2) implement the strategy, and (3) do an evaluation of the outcomes.

The first thing to consider before planning the strategy is the external condition of the company. We can use PESTEL or Political, Economic, Social, Technology, Environment, and Legal analysis to grasp the external condition. The next step is to analyze the internal condition of the company. Using SWOT analysis, supplemented with observation and interview with related parties, the gathered information is analyzed and translated into strengths, weaknesses, opportunities, and threats faced by the firm. Using SWOT analysis as an input, the strategies that takes into consideration firm internal and external condition to 
boost firm performance can be formulated. After formulating the strategies, the next step is to choose what is the most suitable strategy to implement.

\section{Results And Discussion}

\subsection{Choosing the most suitable strategy to implement}

Using SWOT, the first strength of Soul Sepatu Rawamangun lay in its strategic location. The store location of Soul Sepatu Rawamangun is close to a university and several high schools. The main customer segment of Soul Sepatu is students, so with this strategic location, Soul Sepatu should have an advantage compared to other competitors. The second strength is the ability to produce the needed supplies in-house. In-house production of supplies can help in controlling and even reducing costs. With reduced costs, the profit margin will increase. The third strength is the faster shoe treatment process time compared to other competitors. Soul Sepatu implement three days standard in processing customer order. It could be longer depending on the difficulty, but mostly the process only needed three days. The surrounding competitors offer five days to one week of standard processing time. With this strength, customers who need their shoes to be cleaned or repaired faster will most likely choose Soul Sepatu over other competitors.

The main weakness of Soul Sepatu Rawamangun is the lack of marketing communication program. This could result in the lack of customer awareness toward Soul Sepatu. Interviews and questionnaires prove that customers are unaware about Soul Sepatu even though they live near the store of Soul Sepatu Rawamangun. They thought that Soul Sepatu is the same as "sol sepatu, which is the term for a store specialized in repairing broken shoe sole, hence the "sol" in "sol sepatu". They have no idea that Soul Sepatu is a place that can not only repair but also clean customers shoes. Some customers do not even know what shoe laundry is. Another weakness of Soul Sepatu is the lack of personnel. It is hard to search for people willing to work for an SME.

Opportunities and threats can also be analysed using SWOT analysis. The main opportunity is the fact that the current customer segments of Soul Sepatu Rawamangun have not been maximized yet. It means there is still plenty of room to increase the sales number of Soul Sepatu Rawamangun. In the later stage of this business coaching, COVID-19 pandemic emerges in Indonesia. The pandemic is causing the government to employ drastic measures to minimize the casualties. One of the measures is the regulation regarding social distancing called "Pembatasan Sosial Berskala Besar" or PSBB in Jakarta, Indonesia. This regulation forces people of Jakarta to minimize outdoor activities. This regulation also forces many companies to momentarily stop or minimize their business activities. This threatens the sustainability of many companies including Soul Sepatu because there is almost no customer.

The next step after analysing every strengths, weaknesses, opportunities, and threats is to choose what strategy to be used to exploit strengths and opportunities or minimize weaknesses and threats. Each strategy has its own advantage and disadvantage. They also have different impact regarding the time and cost needed to implement. To help deciding which strategy to choose, the coach together with the business owner discuss which strategy is appropriate. The considerations in choosing the strategy is which strategy has the minimum amount of budget needed, the least time needed to implement, and the easiest to implement. But those considerations are only from the business owner perspective, we also need to consider the customers perspective. One of the considerations from customers perspective are most of the 
community near Soul Sepatu Rawamangun does not know what shoe laundry is. So, we must inform customers about shoe laundry before informing about Soul Sepatu services.

There are two strategies to be chosen, designing promotional mix and adding a delivery service. Designing promotional mix is implemented as a strategy to exploit the opportunity presented by the yet to be maximized customer segment to minimize the weakness of Soul Sepatu, which is the lack of marketing communication. Another alternative strategy to implement is adding a delivery service. The delivery service could help maximize the advantage presented by the strategic location of Soul Sepatu store. But the current lack of personnel becomes the main bottleneck in adding a delivery service. After conducting discussion with the owner and survey to related parties, the most suitable strategy to implement is chosen. The chosen strategy is designing promotional mix. The main reason for choosing promotional mix is due to budget and time needed for the implementation. Designing promotional mix is cheaper than hiring another personnel for delivery service on the short term. Designing promotional mix is faster to implement compared to searching for people willing to be a courier.

\subsection{The right mix of promotional mix}

The next step is designing each mix of promotional mix and there are six of those that can be used. Those mix are advertising, direct marketing, digital/internet marketing, sales promotion, publicity/public relation, and personal selling. Another discussion with the owner is needed to decide whether to implement some of the mix or implement all of them. As explained before, SME have tight concerns regarding money, time, and ease of implementation. There are also other considerations from the customer perspective.

The owner comment that the promotional mix design should be developed based on how easy it is to implement. It was so the employee able to easily understand the role they are supposed to do on implementing the promotional mix. It is even more so when we take into consideration that all of the employee only has high school diploma. We also need to design promotion mix that can educate customer about shoe laundry and fulfil their needs of cheap shoe laundry and care. After some consideration and discussion, the owner agrees to implement two mix which is sales promotion and digital/internet marketing.

\subsection{Implementing the promotional mix}

All elements of promotional mix should be designed in a way so that they have a synergizing effect on each other. The first is designing sales promotion mix. Sales promotion basically an incentive to stimulate short term sales. In the case of Soul Sepatu, sales promotion should be able to effectively boost sales in short term. The decision for sales promotion mix is to cut price to one of the services provided by Soul Sepatu called special treatment. The halfprice discount is given for the services of washing customer shoes, or special treatment service as Soul Sepatu called it.

The next mix to design is digital/internet marketing. Previously, Soul Sepatu already has social media account that can be used as a digital marketing channel. Digital/internet marketing use those media to facilitate two-way communication between customers and Soul Sepatu. Because we will have a sales promotion event, the social media account is used to broadcast a message informing the customer about them. The main social media used for this implementation is Instagram due to their ease of use and their large consumer base. The content should also include material about shoe laundry and Soul Sepatu itself, so the 
customers are informed and know how to choose the correct service. This step could also help in increasing the brand awareness of Soul Sepatu.

The implementation of promotion mix is adjusted according to event happen in real-time. It is so the promotion event communicated by Soul Sepatu can stay relevant to customer. Employee education also need to be done so that they are updated with the latest event happened. Employee supervision also important to make sure they understand their role, especially in the early stage of implementation.

\subsection{Evaluation and challenges faced throughout the implementation}

The implementation of promotional mix is already facing trouble in their early stage. The main problem is regarding the employee that will execute the plan. As the employee on-site was first given education about the plan to implement a promotion program, he commented that he is used to his current job and does not feel comfortable with the changing environment. From that comment both the coach and the owner instantly understand that tight supervision will be needed to make sure that the employee executes the plan correctly. Since neither the coach nor the owner will be able to constantly monitor the employee, there are time when the employee forgot to inform customers that Soul Sepatu has a half-price discount. This could lead into dissatisfaction from the customers as they complain about not getting any discount.

Another critical problem happened during the implementation is the emergence of COVID-19 pandemic. The pandemic threatens the company ability, especially SME, to stay operational either due to the lack of customer or government regulation. The pandemic also threatens the sustainability of the business model of Soul Sepatu. Even though the first week of implementation yield positive sales result, the lower customer rate due to pandemic is forcing Soul Sepatu to forgo the sales promotion event because it has the potential to backfire. Looking at the customers fear and worry, it may be a suitable time to implement the alternative strategy which is adding a delivery service. But due to time constraint for the writing of this article, the plan should be implemented on another research.

\section{Conclusion}

The implementation of the strategy through business coaching met with potential benefits and challenges. In the first week of implementation, the sales number of Soul Sepatu did increase compared to previous week. This result is as predicted with the uses of sales promotion that could stimulate short term sales. But, the overall sales of that month are still lower compared to the previous month due to COVID-19 pandemic. Another challenge faced during the implementation is the employee problems that keep appearing when the coach and the owner slacking in their supervision.

This research also demonstrates that external forces can massively influence a business. If the preparation against external forces are not carefully prepared, the business would be unable to survive. Many companies, whether big or small, are shaken due to the sudden appearance of the COVID-19 pandemic. Facing against an external force as massive as COVID-19 pandemic, it is possible that all kind of ongoing strategies could instantly become useless. The answer regarding whether it is possible for the external force to render all ongoing strategies useless is left for future research. 


\section{References}

[1] Kemenperin, "Kemenperin: Indonesia Produsen Alas Kaki Terbesar Keempat Di Dunia," 2019. http://www.kemenperin.go.id/artikel/20539/Indonesia-Produsen-Alas-KakI-Terbesar-Keempat-DiDunia (accessed Jun. 02, 2019).

[2] G. E. Belch and M. A. Belch, Advertising and Promotion: An Integrated Marketing Communications Perspective, 11th Ed. New York: McGraw Hill Education, 2017.

[3] W. G. Mangold and D. J. Faulds, "Social media: The new hybrid element of the promotion mix," Bus. Horiz., vol. 52, no. 4, pp. 357-365, Jul. 2009.

[4] L. E. Boone and D. L. Kurtz, Contemporary Marketing, 16 ed. Ohio: South-Western Publishing Co., 2014

[5] J. Y. Lee, S. Sridhar, and R. W. Palmatier, "The effect of firms' structural designs on advertising and personal selling returns," Int. J. Res. Mark., vol. 34, no. 1, pp. 173-193, Mar. 2017.

[6] F. ur Rehman, R. Bin Md Yusoff, S. Bin Mohamed Zabri, and F. Binti Ismail, "Determinants of personal factors in influencing the buying behavior of consumers in sales promotion: a case of fashion industry," Young Consum., vol. 18, no. 4, pp. 408-424, 2017.

[7] S. K. Sinha and P. Verma, "Impact of sales Promotion's benefits on perceived value: Does product category moderate the results?," J. Retail. Consum. Serv., vol. 52, p. 101887, Jan. 2020.

[8] M. Chaudhuri, R. J. Calantone, C. M. Voorhees, and S. Cockrell, "Disentangling the effects of promotion mix on new product sales: An examination of disaggregated drivers and the moderating effect of product class," J. Bus. Res., vol. 90, pp. 286-294, Sep. 2018.

[9] P. Kotler, H. Kartajaya, and I. Setiawan, Marketing 4.0: Moving from Traditional to Digital. Canada: John Wiley, 2016.

[10] B. M. Crompton, K. X. Smyrnios, and R. Bi, "Measuring the influence of business coaching on fast-growth firms," Small Enterp. Res., vol. 19, no. 1, pp. 16-31, Oct. 2012.

[11] J. Hansson, E. Höög, and M. Nyström, "Action research for multi-level facilitation of improvement in health and social care: Development of a change facilitation approach for a local R\&D unit," Action Res., vol. 15, no. 4, pp. 339-356, 2017. 